\title{
Do the writing methodologies of Greco-Roman historians have an impact on Luke's writing order?
}

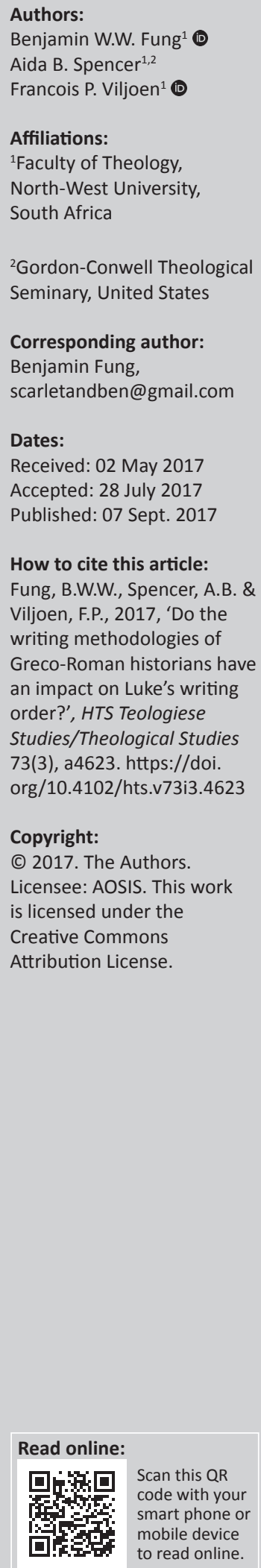

Luke in the preface of his Gospel says that he is going to write 'in an orderly account' (Lk 1:3). However, scholars have no consensus about the kind of order Luke is seeking. Many believe that Luke writes as a historian. Because Greco-Roman historians seem to have a practice to indicate in their prefaces the writing methodologies of their writings, this article aims to ascertain Luke's writing order through a comparison of Luke's two prefaces with those in the writings of the Greco-Roman historians. This article proposes that Luke most likely adopts the common writing methodologies of the Greco-Roman historians and writes in chronological order.

\section{Introduction}

Many believe that Luke writes as a historian (e.g. see Fitzmyer 2008:92; Green 1997:2-3). As there is no indexing system used in ancient writing, it is quite common for Greco-Roman historians to communicate the order of their writings to their readers through the preface so that their readers will know at the outset how the contents will be organised. Therefore, a comparison of Luke's prefaces with those written by other Greco-Roman historians may give insights into Luke's order. This article will be divided into two sections. First, it will compare the preface of Luke's gospel (the first book of Luke-Acts) with the prefaces of the first books of the writings of Greco-Roman historians; second, this article will compare the preface of the Book of Acts (a sequel to the Gospel) with the prefaces written in the sequels of the writings of Greco-Roman historians to see whether there is (are) hint(s) for Luke's writing order. An overall conclusion will follow.

This article complements the author's article What does $k \alpha \theta \varepsilon \xi \tilde{\eta} \varsigma$ in Luke 1:3 mean? Discovering the writing order of the Gospel of Luke, ${ }_{1}^{1}$ which proposes that if $k \alpha \theta \varepsilon \xi \tilde{\eta} \zeta$ indicates Luke's writing order, the writing order is most likely chronological. This article will demonstrate an independent consideration: if the Greco-Roman historians do not state the order they are going to use in their writings, they will write in chronological order. If this observation is correct, and if Luke does not mention in the prefaces what kind of writing order he uses, we can still reasonably believe that he is writing his two books in chronological order. Therefore, no matter whether Luke has clearly indicated his writing order in his prefaces, as shown by $k \alpha \theta \varepsilon \xi \tilde{\eta}$ s, or not, the author will still show that he likely writes in chronological order.

\section{A study of the preface of Luke's gospel}

A study of the writings of the Greco-Roman historians (see Appendix 1) finds that the prefaces of their first books usually include the following four elements: what the historian will write (the content), why the historian writes this narrative (the reason[s]), how the narrative will be written (the methodology - it usually tells what source materials will be used and in what order the narrative will be written) and sometimes what the historian expects from the readers (the expected result[s]). Each historian will sequence these four elements differently (see Table 1). Writing as a historian, Luke also includes all four elements above in his preface.

There appears to exist a general understanding between the historians and their readers that if they do not state clearly in what order they will write their histories, they are going to write in a certain order. If this is the case, the historians do not need to state their writing order explicitly if they do not deviate from that custom. They will have to mention their writing order only when

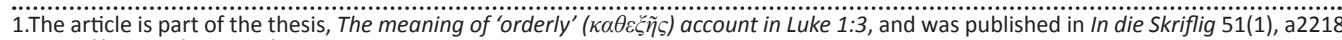
(http://doi.org/10.4102/ids.v51i1.2218) on 23 May 2017. The article presents different scholarly opinions on the meaning of 'orderly' and proposes that the Gospel of Luke is written in strict chronological order. This argument is further supported and elaborated in the thesis, where a detailed discussion of the writing techniques for narratives of Greco-Roman historians (a part of these techniques is briefly discussed in note 3 ) and a detailed analysis of Luke's narratives together with those of Matthew and Mark's are conducted.

Note: This article is based on a part of the thesis, The meaning of 'orderly' ( $\kappa \alpha \theta \varepsilon \xi \tilde{\eta} \varsigma$ ) account in Luke 1:3, presented to North-West University for Dr Francois Viljoen and Dr Aida Besancon Spencer. 
TABLE 1: The four elements Luke includes in the preface of his Gospel.

\begin{tabular}{|c|c|}
\hline Elements included in Luke's preface & Corresponding verses (description) \\
\hline 1. Reason why he writes his Gospel & $\begin{array}{l}\text { Verse } 1 \text { (because there are others writing } \\
\text { narratives about Jesus) }\end{array}$ \\
\hline 2. What he will write (content) & Verse 3 (another narrative about Jesus) \\
\hline 3. Methodology of writing & $\begin{array}{l}\text { Verses } 2 \text { to } 3 \text { (carefully investigating all the } \\
\text { eye-witness accounts to ensure correctness } \\
\text { and writing them in an orderly manner) }\end{array}$ \\
\hline $\begin{array}{l}\text { 4. Luke's expectation of his reader } \\
\text { Theophilus }\end{array}$ & $\begin{array}{l}\text { Verse } 4 \text { (he hopes that Theophilus' faith } \\
\text { will be strengthened) }\end{array}$ \\
\hline
\end{tabular}

they intend to write in a different order. This section will study the writings of some of the most famous Greco-Roman historians (5th century BC -3 rd century A.D.) to ascertain whether there are common rules about the order of writing which Greco-Roman historians would adopt when writing their histories. The following historians and their writings are chosen for this study: ${ }^{2}$ Herodotus (The Persian Wars), Thucydides (The Peloponnesian War), Xenophon (The Way of Mounting), Polybius (History), Pausanias (Description of Greece), Philostratus (The Life of Apollonius of Tyana), Josephus (The Life, Against Apion, The Jewish War) and Eusebius (The History of the Church). This article will conduct an analysis of the order each historian uses. The author of this article will argue that Luke likely adopts the writing methodologies of the Greco-Roman historians; and these methodologies give hints as to Luke's writing order, which is very likely chronological.

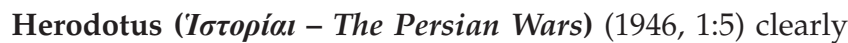
states the order:

These are the stories of the Persians and the Phoenicians. For my own part, I will not say that this or that story is true, but I will name him whom I myself know to have done unprovoked wrong to the Greeks, and so go forward with my history, and speak of small and great cities alike. For many states that were once great have now become small: and those that were great in my time were small formerly. Knowing therefore that human prosperity never continues in one stay, I will make mention alike of both kinds.

Herodotus's Persian Wars, therefore, may not be written in chronological order. It may be written in a certain logical order to describe the events that happened for each Greek city as stated by Herodotus in Book 1 .

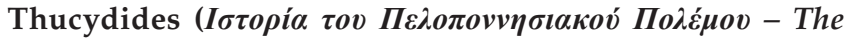
Peloponnesian War) does not explain at the beginning of Book 1 in what order he is going to write. He only says he writes the history of the war 'beginning at the moment that it broke out'. However, the events are obviously recorded in chronological order, which is evidenced by the content itself and by Thucydides' comment in Book 2 (1996, Pel. war 2:1): 'The events of the war have been recorded in the order of their occurrence, summer by summer and winter by winter', and his other comment in Book 5 (1996, Pel. war 5.26): 'The history of these events also, has been written by writings are considered by her to be relatively renowned and representatives among the writings of Greco-Roman historians. the same Thucydides, an Athenian, in the chronological order of events, by summers and winters ...'. Therefore, the question is why Thucydides does not mention at the outset that he is going to write The War in chronological order. Considering that there is no table of contents and no indexing system in the Greco-Roman world, the readers might be disinclined to read such a long book without knowing how the book is organised. One probable explanation is that there exists an understanding in the Greco-Roman world between the historians and their readers that if a historian does not mention at the outset in what order he will write his book, then the book is written in chronological order.

A study of the first section of each book (from one to seven) of Avó $\beta \alpha \sigma \iota \varsigma$ [the Way of Mounting] shows that Xenophon does not mention in what order he will write. However, from the content it seems that Xenophon has recorded the events in chronological order. For example, in Book 1, Xenophon describes the background of the story in the following order: how Artaxerxes rises to power to become the emperor of the Persian Empire, how he ill-treats his younger brother Cyrus after he becomes emperor, how Cyrus then determines to overthrow him and plots against him, how Cyrus gathers his troops, how Artaxerxes and Cyrus fight against each other and how Cyrus is killed in battle. The analysis above seems to support the hypothesis that if a historian does not state the writing order, then he is writing in chronological order.

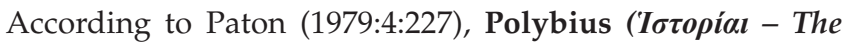
Histories) summarises the events of each Olympiad starting from the 129th Olympiad. He states in each of his books the order he will use, usually at the very beginning, in the preface. For example, in Book 1 (Hist. 1.5) he says:

I shall adopt as the starting-point of this book the first occasion on which the Romans crossed the sea from Italy. This follows immediately on the close of Timaeus' History and took place in the 129th Olympiad. Thus we must first state how and when the Romans established their position in Italy, and what prompted them afterwards to cross to Sicily, the first country outside Italy where they set foot ...

At the beginning of each book, Polybius usually summarises what he has narrated in the previous book before he states the order in which he will write the next book. For example, in Book 4 (Hist. 4.1) he says:

In the preceding Book ... I described the invasion of Italy by Hannibal ... I shall now give an account of the contemporary events in Greece from the 140th Olympiad onwards, after briefly recalling to the minds of my readers the sketch I gave in my second book ... Next I went on to tell how they subsequently began to reunite ...

Sometimes Polybius gives a brief description of what he will write for the next book at the end of a particular book. If this is the case, usually there will be no preface or explanation of order at the beginning of the next book. For example, in Book 4 (Hist. 4.87) he says: 
As to how and by what means this happened, I shall defer speaking for the present and bring this Book to a close; but in subsequent ones I shall try to give a clear account of the whole matter, Philip, after making the arrangements I mentioned, returned to Argos and there spent the remainder of the winter with his friends, dismissing his troops to Macedonia.

There is no preface or explanation of order at the beginning of Book 5. Polybius' summaries at the end of his books seem to be a writing technique suggested by Lucian: a historian should structure his writing so that 'the first and the second topics must not merely be neighbors but have common matter and overlap' (Lucian 1999:67). This overlapping writing technique is frequently employed by Luke in his gospel. ${ }^{3}$

Polybius narrates the events in the Histories in the chronological order of the Olympiads. This is evidenced by the years of occurrence of many of these events put down by Paton in the margin alongside with the contents of the Histories. But, if this is true, why did Polybius have to give a preface in almost every book or to give a description at the end of a book regarding how he will write in the next book? If my hypothesis applies, that there exists an understanding among the readers that if a historian does not mention the writing order then he is writing in chronological order, then apparently Polybius does not have to write the prefaces and the ending descriptions if he writes in chronological order. However, in Polybius' case, there is a change of content as compared with the previous book, and, therefore, Polybius has to give a summary of what he is about to write in each book. This reason will be addressed in greater detail in the next section ('A study of the preface of the Book of Acts').

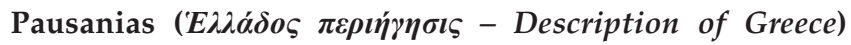
does not mention anything about order at the beginning or at the end of each book. However, it seems that whenever he describes an important family or the history of a city, he writes in chronological order. For example, in Book 1, when Pausanias describes Lysimachus and his family, he starts with Lysimachus (Descr. 1:9), then describes Lysimachus' son Demetrius (Descr. 1:10), then Demetrius' son Antigonus (Descr. 1:10). The family is described in chronological order from grandfather to father to son. Another example is Pausanias' history of a city called Orchomenus in Book 9 (Descr. 9:34-38). Andreus is the first king, who founds Orchomenus. He then gives the throne to Athamas. The throne then goes to Eteocles, the son of Andreus, and next to Phlegyas the son of Almus. Phlegyas is followed by Chryses, son of Chrysogeneia, because he has no son. Minyas son

\footnotetext{
3.This writing technique and how it impacts the writing order of Luke's gospel is discussed in detail in chapter 3 in the author's thesis The meaning of 'orderly'

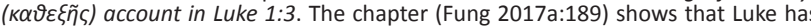
divided his gospel into 12 sections by means of summary account statements $(1: 80$ $2: 40,2: 52,3: 19-20,4: 14-15,4: 42-44,8: 1-3,9: 51-52 a, 19: 45-48,21: 37-22: 6$ and 24:44-49) and has recorded them in overlapping chronological order. Luke seems to have structured these sections so that each section has a common subject(s) of have structured these sections so that each section has a common subject(s) of discussion with the section immediately before and after it. At the end of each section, there is a summary account statement, which serves as a brief summary ending that section, and most of the time also giving a preview of the next section. The preview's implied time frame also overlaps the time frame of the immediately following section. As summary account statement is only a common Greco-Roman historian writing technique employed by Luke, it does not undermine his intention to write his gospel in strict chronological order.
}

of Chryses then becomes king, followed by his son Orchomenus. The throne then passes to Clymenus because Orchomenus has no son. His son Erginus follows Clymenus as king, the throne then being taken by Ascalaphus and Ialmenus, sons of Ares. It is evident that Pausanias presents the rulers in chronological order. Therefore, it seems that Pausanias' writing order confirms the hypothesis that absents any statement to the contrary, a historian writes in chronological order.

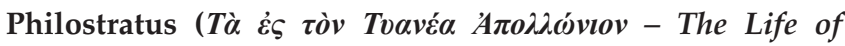
Apollonius of Tyana) does not specify in what order he writes The Life of Apollonius of Tyana. The book describes events from the very beginning, relating to Apollonius' birth (Life Apoll. 1:4-6), to the very end, relating to his death (Life Apoll. 8:30). Afterwards, it even records an incident related to Apollonius after his death (Apollonius converses with a young man) (Life Apoll. 8:30). The content therefore shows that it is basically written in chronological order. It seems that Philostratus' writing order also follows the above hypothesis, that if the writing order is not stated, a historian writes in chronological order.

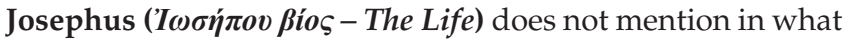
order he writes The Life. However, the content seems to indicate that it is written in chronological order. This is also supported by the years of occurrence of the many events put down by Thackeray throughout the whole book in the margin alongside with the contents of The Life. ${ }^{4}$ It seems that Josephus' The Life also follows the above hypothesis that the order is chronological if the historian does not specify otherwise.

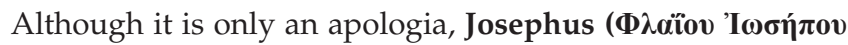

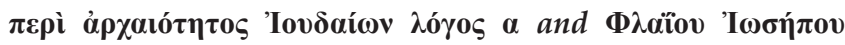

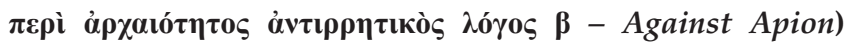
does mention in Book 1 of Against Apion (1926, Ag. Ap. 1:58) in what order he will write:

I propose, in the first place, to reply briefly to those critics who endeavour to prove the late origin of our constitution from the alleged silence of the Greek historians concerning us. I shall then proceed to cite testimonies to our antiquity from external literature, and finally to show the utter absurdity of the calumnies of the traducers of our race.

Josephus is writing his Against Apion in a logical order to defend the antiquity of his race and to rebuke the allegations from Jewish enemies. The writing order is described explicitly in the preface as not chronological, but in a certain logical order to achieve the historian's purpose.

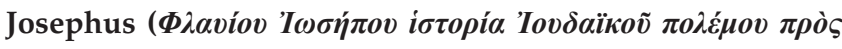

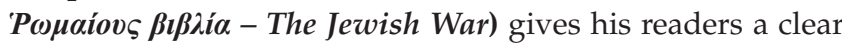
description of the order he will use at the beginning of Book 1 (J.W. 1:7-12): Antiochus takes over Jerusalem but is expelled

4.For example, Thackeray gives the dates of the following events alongside the text in Life 1.1: Matthias marries the daughter of Jonathan the high-priest (153 BC); Matthias has a son Matthias in the first year of the reign of Hyrcanus (135 BC); Joseph, son of Matthias is born (70 BC); Josephus, a descendant in the line, is born (AD 6). The dates indicate that these events are described in chronological order. 
by the Hasmonaeans; the Hasmonaeans are overthrown by Herod; the war begins after Herod's death, the Jews fortify their towns, the Roman General Vespasian and his son Titus penetrate Galilee, the Romans advance against Jerusalem, which eventually falls. It seems that the Jewish War is basically written in chronological order. This is evidenced by the date of occurrence of many events noted by Thackeray throughout the book in the margin alongside with the contents of the Jewish War. ${ }^{5}$ It seems that though Josephus has mentioned explicitly a logical writing order in the preface focusing on major events from the origin to the end of the war, he also writes them chronologically. It indicates that even though a historian might have described explicitly in the preface writing in a certain logical order, he can also use chronological order together with that logical order to present the historical events he is about to write.

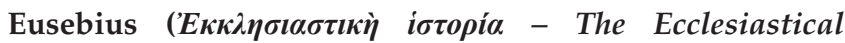
History) in Ecclesiastical History (1.1.7-8) clearly states that he will write that particular book in a certain order to discuss Jesus' divinity. Although Eusebius does not explain in the introduction sections of Books 2 to 10 of the Ecclesiastical History in what order he is going to write these books, the content shows that they are written in chronological order. The events are seemingly narrated according to the time of reign of each Roman Emperor. This is supported by at least two comments he gives in the Ecclesiastical History. The first comment is recorded in Book 1 (Hist. eccl. 1.1.6) where Eusebius says that he has already summarised certain

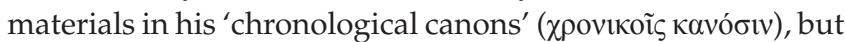
he is going to give the narrative in full detail. Therefore, there is a high probability that Eusebius extends his summarised materials based on the order of his 'chronological canons' and writes his Ecclesiastical History in chronological order.

The second comment is recorded in Book 3 (1965, Hist. eccl. 3.4.11), where Lakestranslates as 'now as we go on our way, the "chronological details" of the succession of the Apostles

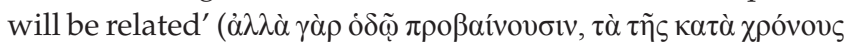

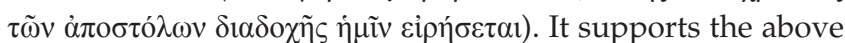
observation that he is writing Books 2 to 10 of the Ecclesiastical History in chronological order. The study of Eusebius' Ecclesiastical History again supports the hypothesis that if a historian does not specify the writing order at the outset, he is probably writing in chronological order.

\section{Conclusion}

This article has three observations regarding the writing order of ancient Greco-Roman historians. Firstly, GrecoRoman historians will usually state in the preface in what order they will write. This is probably because many writings tend to be quite long and there was no indexing system; therefore, the historians use this approach to communicate to their readers at a glance what their writings are about and

5. For example Thackeray has added the dates of the following events in the right margin alongside the text: the death of Matthias, the father of Judas (167 BC, 1.37) Judas gains control of the upper city (165 BC, I.39a); the death of Antiochus (164 BC, Judas gains control of the upper city (165 BC, I.39a); the death of Antiochus (164 BC,
I.39b); the death of Judas and his brother John (161 BC, I.47). The dates indicate that these events are described in chronological order. how the contents are organised. Secondly, there seems to be an implicit understanding between the historians and the general readers that if a historian does not state the order, he is going to write in chronological order. Thirdly, GrecoRoman historians sometimes will state in their prefaces that they will write in a certain logical order, though their writings are basically organised in chronological order. That is, they write in both chronological order and a specific logical order. Apparently, it happens when a historian wants to highlight certain important events in his book to convey a message that supports the main theme of his writing.

In conclusion, the findings of this section support the proposal that if Luke does not mention in the preface (Lk 1:1-4) what kind of order he is using, he is probably writing in chronological order. He may also have a logical or thematic purpose for the events, but that will not undermine the chronology.

\section{A study of the preface of the Book of Acts}

This section will compare the prefaces of sequels written by Greco-Roman historians and their writing orders with the preface in the Book of Acts, hoping that the exercise will shed further light on Luke's writing order. In this section, the author will argue that Luke likely follows the approach used by other Greco-Roman historians in writing prefaces for sequels. If this is true, the writing order of Acts is the same as OR, is similar to that in the Gospel of Luke.

It seems that Luke does not follow the general approach of the Greco-Roman historians in structuring the preface (Acts 1:1-5) of Acts because this preface, unlike the preface of his Gospel, does not seem to include any of the four components (what content the historian is going to include, his reason(s) for writing, the methodology which will be used for writing and the expected result from the reader[s]) the Greco-Roman historians usually used in writing prefaces. However, a study of their writings shows that Luke's approach is similar to the approach adopted by some Greco-Roman historians in writing prefaces for sequels. When some Greco-Roman historians write prefaces for sequels, they give only a brief description of what they have written in the previous book and then go on to describe what they are going to write in the current book.

Luke appears also to use this approach when he writes the preface for Acts. For example, Polybius usually gives a summary at the beginning of each book of Histories about what he has written in the previous book, and then will explain what he will write in that particular book. For example, Polybius (1979) in Histories 4.1 writes:

In the preceding Book ... I described the invasion of Italy by Hannibal ... I shall now give an account of the contemporary events in Greece from the 140th Olympiad onwards, after briefly recalling to the minds of my readers the sketch I gave in my second book ... Next I went on to tell how they subsequently began to reunite ... 
Also, in Book 2.1 of Against Apion, Josephus (1926), when writing the preface for this sequel, follows the same approach to describe briefly what he has written in the previous book and what he will write in the current book: 'In the first volume of this work, my most esteemed Epaphroditus, I demonstrated the antiquity of our race ... I shall now proceed to refute the rest of the authors who have attacked us'.

However, not all Greco-Roman historical writings which have a preface for the first book have prefaces for their sequels. For example, Herodotus includes a preface only in the first book of his Persian Wars but not in the other books (i.e. Books 2 to 9); Thucydides writes prefaces only for the first and second books of his Peloponnesian War but not for the rest (Books 3 to 8); Josephus also follows this approach for his Jewish War and writes a preface only for the first book but not for the others (i.e. Books 2 to 7); and Philostratus writes a long preface describing all four elements (reason, content, methodology and expected result) in the preface of the first book of his Life of Apollonius of Tyana (sections 1 to 3) but does not also write a preface for the rest (Books 2 to 8). Why are prefaces written for some Greco-Roman historian sequels but not for others? Is there a common practice for writing prefaces for sequels that the Greco-Roman historians adopt only when writing under certain circumstances? If so, what are these circumstances? And does Luke, when writing a preface for Acts, a sequel to his Gospel, follow this common practice? And, if this is the case, what is the significance, if any, of this common practice for Luke's preface in the book of Acts? Is there any significance for Luke's writing order for his Gospel and Acts?

A study of Herodotus, Thucydides, Polybius, Philostratus and Josephus finds that while these historians usually write a preface at the beginning of the first book of their histories, they will write a preface for a sequel only when one or more of the four elements (content, reason, methodology and expected result) described before will be changed from that sequel onwards. In such a case, a historian will usually describe in the preface of that sequel what has been written in the previous book, probably as a refresher to his reader(s) and a connector between the previous and the current book, and then he will describe the change(s) together with what he is about to write in the current book.

Sometimes a historian may reiterate in the preface of a sequel a particular element which has already been mentioned in the preface of a previous book even though it will not undergo any change, in order to emphasise its importance to the reader(s). However, in general the historians will not mention in the preface of a sequel those elements which will remain unchanged, no matter whether that element is mentioned explicitly in the preface of a previous book or is only implied in the previous content.

In Herodotus' Persian Wars (with a total of 9 books), Philostratus' Life of Apollonius of Tyana (8 books) and Josephus' Jewish War (7 books), while the historians write a preface at the beginning of their first books, they do not write a preface for the sequels. A brief study of the contents of their writings seems to support the argument that because the content, the reason, the methodology and the expected result all remain unchanged throughout these writings, there is no need for a preface for the sequels.

In The Peloponnesian War (8 books), Thucydides writes prefaces only for Books 1 and 2, and, in a quite unusual manner, he also writes an introduction, which is similar in content to a preface, in the middle of Book 5 (5.26). A comparison of Books 1 and 2 reveals that the content of the two are basically different. In Book 1 , Thucydides seemingly only gives background information - he only explains the relationships and the conflicts between various states but does not describe the war itself. He only begins to describe the war in Book 2. This observation is confirmed by what Thucydides (1996) writes in the preface of Book 2:'at this point in my narrative begins the account of the actual warfare between the Athenians and the Peloponnesians and their respective allies' (2:1). Moreover, in the preface of Book 2, Thucydides describes his methodology of writing, which he does not do in the preface of the first book: 'the events of the war have been recorded in the order of their occurrence, summer by summer and winter by winter' (2:1).

Based on the above observations, Thucydides probably writes a preface for Book 2 because the nature of the content in Book 2 onward will be different from that in Book 1 ; he has to make it clear to his readers what he is going to write from Book 2 onwards. Thucydides also describes the writing order he is going to use from Book 2 onward, an element which he does not mention in the preface of the first book. It either implies that Book 1 is not written in that same order (i.e. he states it in the preface of Book 2 because there will be a change in the writing order beginning with Book 2) or that he wants to emphasise this order to his readers because of its importance. Regarding the reason, Thucydides writes an introduction in 5.26 (Thucydides writes):

the history of these events, also, has been written by the same Thucydides, an Athenian, in the chronological order of events, by summers and winters, up to the time when Lacedaemonians and their allies put an end to the dominion of the Athenians and took the Long Walls and Peiraeus. Up to that event the war lasted twenty-seven years in all ...

the author agrees with T. E. Page ${ }^{6}$ that this is written because at this point Thucydides has decided to enlarge the scope of his writing from the first 10 years to the first 27 years (i.e. there is a change in the scope of the content). The last sentence in 5:25 ('but at last they were forced to break the treaty which had been concluded after the first 10 years, and again engaged in open war') also supports this argument. Here Thucydides reiterates the writing order which he has already described in the preface of Book 2 ('in the chronological order of events, by summers and winters'). This is probably because

6.Page opines that 'this chapter forms a kind of second introduction, and was probably written after the author enlarged his plan from a history of the first ten years to that of the whole war' (Thucydides 1996, vol.3:48). 
Thucydides considers the writing order to be an important element and wants to emphasise it to his readers. Based on the descriptions of the writing order in the preface of Book 2 and the introduction section in Book 5 (5.26) and the content itself, Thucydides' Peloponnesian War is clearly written in chronological order. This observation supports the argument that if an element (here the writing order) is not mentioned in the sequels, it will remain unchanged as it is in the previous books. Besides Books 2 and 5, Thucydides does not mention the writing order again, but the evidence shows that the writing order is consistent and has not been changed throughout the work, remaining the same as described in Books 2 and 5.

In the first eight books of The Histories, ${ }^{7}$ Polybius writes a preface for almost every book. In the prefaces he will usually summarise what he has narrated in the previous book before stating what he will write and in what order in the current book. Sometimes, Polybius will give a brief description of what he will write for the next book at the end of a particular book, and, when this is the case, usually there will be no preface at the beginning of the next book (see 2.3.3.4). The reason Polybius writes a preface for almost every book is probably that unlike Thucydides or Herodotus he is not describing a particular war or event; but as Finley (1971:441) says, The Histories is about a universal history: Rome's conquest of the world from 220 to 144 BC including the final conquest of Spain, Africa and Greece. The material Polybius is going to write is so diverse that it is impossible for him to give his reader a brief summary of all the individual events in the preface of the first book. What Polybius does there is to give his reader a general explanation of what he is going to write (according to Hist. 1.1.5-6, his objective is to write about how the Romans in such a short period of time have succeeded in conquering the whole world) and then to summarise the events he is going to describe in each book in its preface. The preface of a particular book is therefore a description of the new events he will describe in that book. In summary, Polybius writes a preface for each book probably because there is a difference in the content of each book as compared with the previous one.

In Jewish Antiquities (20 books), Josephus writes a preface only for Books 1 and 14. The preface at the beginning of Book 14, according to R. Marcus (see Josephus' Jewish Antiquities 1926, vol. 6:3), is written probably because Josephus will begin to use Nicholas of Damascus as his chief source from Book 14 onwards. Considering that in the preface of Book I section 3 Josephus states that he will use the sacred Scriptures (the Hebrew and the Greek Scriptures) as his chief source and will follow them closely to write his books, it represents a change of chief source from Book 14 onwards (i.e. a change in his writing methodology). Also, in the preface of Book 14 Josephus reiterates two elements he has already mentioned in the preface of Book 1: comprehensiveness and accuracy elements which he probably believes to be very important in this work.

7.Only fragments for most other books are available; therefore, no study is conducted for them.
In Against Apion (2 books), Josephus writes a preface for both Books 1 and 2. A study of the prefaces of the two books finds that the content of these two books is seemingly different in nature: in the first book, Josephus (1926) focuses mainly on his demonstration of the antiquity of the Jewish race through writings from various nations, while in the second book he focuses mainly on refuting the negative statements given by enemies (in the preface of his second book he writes):

In the first volume of this work, my most esteemed Epaphroditus, I demonstrated the antiquity of our race, corroborating my statements by the writings of Phoenicians, Chaldaeans, and Egyptians ... I shall now proceed to refute the rest of the authors who have attacked us.)

If the above observation is true, the reason why Josephus writes a preface for Book 2 is probably that the nature of the content of Book 2 is different from that of Book 1.

If Luke has followed the common practice of the GrecoRoman historians in writing a preface for the book of Acts because one or more of the four elements (content, reason, methodology and expected result) described in the preface of his Gospel has been changed in Acts, then what is changed? The preface of Acts indicates that it is the content. The Gospel

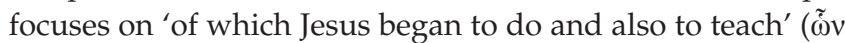

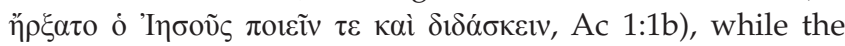
content of Acts focuses on 'the promise of the Father' ( $\tau$ ๆे

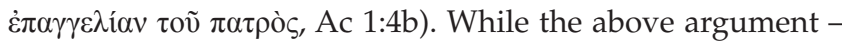
that the focus of the Gospel of Luke is on Jesus' actions and teachings - can easily be supported by the content of the Gospel itself, the argument that the focus of the book of Acts is on the promise of the Father is supported by the way Luke structures his preface in Acts, gradually guiding his reader Theophilus to focus on this subject. The structure is analysed as follows.

At first glance, it seems that Luke does not state in the preface what he is going to write in Acts. However, a comparison of Acts 1:1-5 with the Gospel of Luke (see Appendix 2) reveals that Luke actually does indicate what he is going to write. In the preface, Acts 1:1-2 is a brief summary of the whole Gospel of Luke. Acts 1:3 is a summary of Luke chapter 24, the last chapter of Luke's Gospel. Acts 1:4a 'and while being assembled he commanded them not to depart from Jerusalem

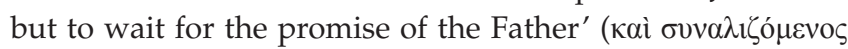

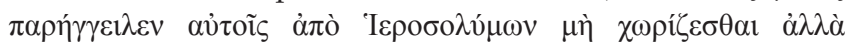

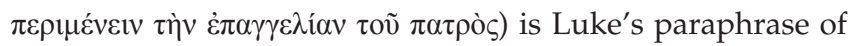
Jesus' message in Luke 24:49a, the first half of the last verse in Chapter 24 before Jesus' ascension 'And behold I am sending the promise of my Father to you; but you stay in the city' (кaì

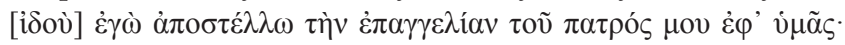

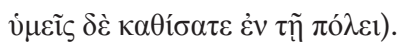

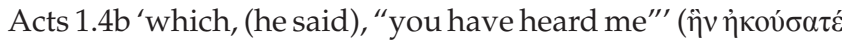
$\mu \mathrm{ov})$, together with 1:5 'that on one hand John baptized with water, on the other hand you in the Holy Spirit will be

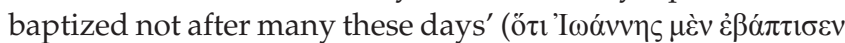

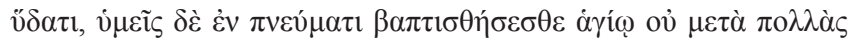

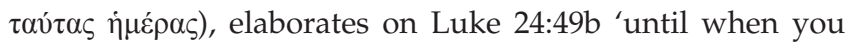




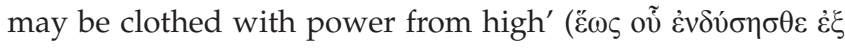

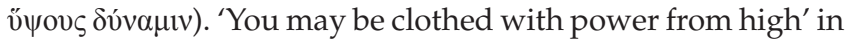
Luke $24: 49 \mathrm{~b}$ can now be understood as 'you in the Holy Spirit will be baptized'. From the above analysis, it appears that while in the preface Luke is giving a brief summary of what he has written in his Gospel to Theophilus, he highlights chapter 24 from his Gospel and then from chapter 24 he highlights verse 49. Judging from Luke's usage of Acts 1:5 to elaborate the meaning of the promise of the Father in Luke $24: 49 \mathrm{~b}$, he seemingly structures the preface in Acts to focus on this promise. Moreover, this promise of the Father is further elaborated in Acts 1:8, which describes what will happen after the apostles are baptised by the Holy Spirit:

But you will receive for yourselves power after the Holy Spirit comes upon you; and you will be my witnesses in Jerusalem and in all Judea and in Samaria and as far as the end of the earth.

It is therefore reasonable to believe that in Acts, Luke wants to write to Theophilus about the promise of the Father, which is mentioned in both Luke 24:49 and Acts 1:4-5 and is further elaborated in Acts 1:8. The content of Acts also supports such an observation. The whole book actually revolves around the fulfilment of this promise: after the preface in 1:1-5, Luke elaborates on the theme of Acts (the promise of the Father) in $1: 8$, and then describes Jesus' ascension and what happened before the coming of the Holy Spirit in 1:6-26. Luke then goes on to narrate the fulfilment of this promise: in 2:1-47 the Holy Spirit comes; in 3:1-7:60 with the power of the Holy Spirit the apostles spread the gospel throughout Jerusalem; in 8:1-12:24 through the lead of the Holy Spirit, the disciples carry the gospel to Judea and Samaria; in 12:25-21:16 Paul, Luke and other disciples, empowered by the Holy Spirit, circulate the gospel to much of the empire on three missionary trips; and in 21:17-28:31 Paul is arrested but the Holy Spirit uses this event finally to spread the gospel to Rome. Therefore, based on the above analysis, Luke does indicate what he is going to write in Acts: the promise of the Father (i.e. with the coming of the Holy Spirit, the apostles and disciples will be empowered to spread the gospel from Jerusalem to the rest of the world, notwithstanding their limitations in financial resources and manpower. $)^{8}$

In summary, Luke writes his Gospel and Acts as a historian and follows the approaches commonly used by the GrecoRoman historians in writing histories. Although Luke

8.Many scholars comment on the theme of Acts, but not all of them explain the difference of contents between the Gospel of Luke and Acts. A study of the works che Schnabel 2012) finds that only three describe the change of contents. They all share the same view that while the Gospel describes all that Jesus begins to do and teach, Acts records the continuation of Jesus' work through the apostles and believers, empowered by the Holy Spirit. This is much like the promise of the Father discussed here. The comments of the three scholars are as follows. Peterson (2009) opines that: 'all that Jesus began to do and to teach until the day he was taken up to heaven summarizes the contents of Luke's former book ... The opening verses of Acts suggest that Luke is about to narrate what Jesus continued to do and to teach after his ascension, through his Spirit and the ministry of his followers' (p. 102). Schnabel (2012:not available) believes that: in the first volume, Luke described the beginning of Jesus' work and teaching in the second volume, he now describes the continuing work of Josus through the Holy Spirit in the ministry of the Twelve the continuing work other believers such as Stephen, Philip, and Paul, and Marshall is of the view that the first book is of course the Gospel, which is sum and Jesus began to do and teach .... (and Acts is about the continuation of Jesus' work) so that Luke is associating what Jesus began to do during his ministry with (implicitly) what he continued to do after his ascension; the ministry of Jesus was the beginning of Christianity. indicates in the preface of Acts that there will be a change in content as compared with that in his Gospel (from a description of what Jesus began to do and to teach, to a description of the promise of the Father, which is about the coming of the Holy Spirit and the Spirit-filled ministries of the apostles and disciples in spreading of the gospel), Luke does not mention in the preface what other elements (i.e. reason, methodology including the writing order, and expected result) will be changed. Based on the above observation that if a Greco-Roman historian does not mention an element in the preface of a sequel that element will remain unchanged from the previous book, this writer reasonably concludes that Luke uses the same writing order for the book of Acts as for his Gospel. If this observation is true, it means that if the author can prove that Acts or the Gospel is written in a certain order (e.g. chronological order), the author may declare that the other book is also written in that order.

\section{Overall conclusion}

A study of the prefaces written by other Greco-Roman historians yields the following observations:

1. Greco-Roman historians, when writing prefaces for the first book in a series, usually include most of the following four components: what the historian will write (content), why the historian writes this narrative (reason), how the narrative will be written (methodology) and what the historian expects from the reader (expected result);

2. there appears to be an understanding between GrecoRoman historians and their readers that the historian will state in the preface of the first book in what order he will write - which is part of the methodology. If the writing order is not stated, he will write in chronological order;

3. Greco-Roman historians write a preface for a sequel only when one or more of the four components (content, reason, methodology and expected result) will be changed from that sequel onward. In such a case, the historian will usually describe the change(s) in the preface of that sequel; and

4. there also seems to be a general understanding that if a component is not mentioned in the preface of a sequel, it will remain unchanged from the previous books, no matter whether that element is mentioned explicitly in the preface of a previous book or is only implied in the previous content.

A study of Luke's two prefaces indicates that Luke likely follows the above approaches used by Greco-Roman historians when writing his prefaces. This is evident from two points:

1. The preface of Luke's Gospel includes all four components commonly included by Greco-Roman historians in their prefaces: (a) reason: Luke gives the reason he writes his Gospel in verse 1 - because there are others writing narratives about Jesus; (b) content: Luke states in verse 3 what he will write - a narrative about Jesus; (c) methodology - he describes his methodology of writing in verses 2 and 3 - he has carefully investigated all the 
eyewitness accounts to ensure correctness and he will write them in an orderly manner; and (d) expected result - Luke states his expectation for his reader Theophilus in verse 4 - that Theophilus' faith will be strengthened.

2. The reason Luke writes a preface for the book of Acts, a sequel, then, is that there is a change in content (one of the four components) from his first book, the Gospel. The change is mentioned in the preface of Acts - the Gospel describes what Jesus begins to do and also to teach (Ac 1:1), while Acts describes the promise of the Father (Ac 1:4).

If the above observations are correct that Luke has followed the general approaches used by Greco-Roman historians in writing his prefaces, then it is reasonable to conclude that even if Luke were not to mention any particular writing order in the preface of his Gospel (i.e. $\kappa \alpha \theta \varepsilon \xi \tilde{\eta} \varsigma$ does not indicate any particular writing order), he would likely write his Gospel in chronological order, as other Greco-Roman historians did in the past. Moreover, because Luke does not mention the writing order in the preface of Acts, according to the above observation that if any of the four components is not mentioned in the preface of a sequel then that element will remain unchanged as it is in the previous book, it means that Acts probably shares the same writing order as the Gospel.

\section{Acknowledgements Competing interests}

The authors declare that they have no financial or personal relationships which may have inappropriately influenced them in writing this article.

\section{Authors' contributions}

B.W.W.F. wrote the article under A.B.S.'s and F.P.V.'s supervision.

\section{References}

Barrett, C., 2004, A critical and exegetical commentary on the Acts of the Apostles, T\&T Clark, Edinburgh. (Logos version 6, computer software).

Bock, D., 2007, Acts, Baker Academic, Grand Rapids, MA. (Logos version 6, computer software).

Bruce, F., 1988, The book of the Acts, Eerdmans, Grand Rapids, MA. (Logos version 6, computer software).

Eusebius, 1965, The ecclesiastical history, transl. K. Lake, Harvard University Press, Cambridge, MA.

Finley, M., 1971, The portable Greek historians: The essence of Herodotus, Thucydides, Xenophon, PolyBius, The Viking Press, New York.

Fitzmyer, J., 2008, The gospel according to Luke I-IX: Introduction, translation, and notes, Yale University Press, New Haven, CT. (Logos version 6, computer software).

Fung, B., 2017a, 'The meaning of "orderly" (kathexēs) account in Luke 1:3', PhD dissertation, Faculty of Theology, North-West University.

Fung, B., 2017b, 'What does kathexēs in Luke 1:3 mean? Discovering the writing order of the Gospel of Luke', In die Skriflig 51(1), a2218. https://doi.org/10.4102/ids. v51i1.2218

Green, J., 1997, The gospel of Luke, Eerdmans, Grand Rapids, MI. (Logos version 6, computer software).

Herodotus, 1946, The Persian wars, transl. A.D. Godley, Harvard University Press, Cambridge, MA.

Josephus, 1926, Works, transl. H.J. Thackeray \& R. Marcus, Harvard University Press, Cambridge, MA.

Lucian, 1999, Lucian, transl. K. Kilburn. Harvard University Press, Cambridge, MA.

Marshall, H., 1980, Acts: An introduction and commentary, InterVarsity Press, Downers Grove, IL. (Logos version 6, computer software).

Peterson, D., 2009, The Acts of the Apostles, Eerdmans, Grand Rapids, MI. (Logos version 6 , computer software).

Polybius, 1979, The Histories, transl. W.R. Paton, Harvard University Press, Cambridge, MA.

Schnabel, E., 2012, Acts, Zondervan, Grand Rapids, MI. (Logos version 6, computer software).

Thucydides, 1996, History of the Peloponnesian war, transl. C.F. Smith, Harvard University Press, Cambridge, MA. 


\section{APPENDIX A}

TABLE 1 - A1: Analysis of the components used by Greco-Roman Historians in the prefaces of their first books.

\begin{tabular}{|c|c|c|c|c|c|}
\hline \multirow{2}{*}{$\begin{array}{l}\text { Historian (Time) } \\
\text { (Writing) }\end{array}$} & \multicolumn{5}{|c|}{ Components in the Preface of the Historian's First Book } \\
\hline & $\begin{array}{l}\text { Description of } \\
\text { Content (1) }\end{array}$ & $\begin{array}{l}\text { Description of Reason for } \\
\text { Writing (2) }\end{array}$ & $\begin{array}{l}\text { Description of Methodology of } \\
\text { Writing (3) }\end{array}$ & $\begin{array}{l}\text { Description of } \\
\text { Expected Results (4) }\end{array}$ & $\begin{array}{c}\text { Order of } \\
\text { components }\end{array}$ \\
\hline $\begin{array}{l}\text { Herodotus (birth: } 484 \mathrm{BC} \text { ) } \\
\text { (The Persian Wars) }\end{array}$ & $\begin{array}{l}\text { The long explanation in } \\
1: 1-5 \text { serves as an } \\
\text { explanation of what } \\
\text { Herodotus will write and } \\
\text { as background } \\
\text { information on the war } \\
\text { between the Greeks and } \\
\text { the Persians. (1:1- 'The } \\
\text { Persian learned men say } \\
\text { that the Phoenicians } \\
\text { were the cause of the } \\
\text { feud...') }\end{array}$ & $\begin{array}{l}\text { Pers. wars 1.1: 'in order that the } \\
\text { memory of the past may not be } \\
\text { blotted out from among men by } \\
\text { time, and that great and } \\
\text { marvellous deeds done by } \\
\text { Greeks and foreigners and } \\
\text { especially the reason why they } \\
\text { warred against each other may } \\
\text { not lack renown'. }\end{array}$ & $\begin{array}{l}\text { Pers. wars 1.1: 'What Herodotus the } \\
\text { Halicarnassian has learnt by inquiry is } \\
\text { here set forth ...' (methodology for } \\
\text { collecting information) } \\
\text { Pers. wars 1.5: 'I should proceed at once } \\
\text { to point out the person who first within } \\
\text { my knowledge inflicted injury on the } \\
\text { Greeks, after which I shall go forward } \\
\text { with my history, describing equally the } \\
\text { greater and the lesser cities of men'. (the } \\
\text { writing order) }\end{array}$ & None & $3-2-1-3$ \\
\hline $\begin{array}{l}\text { Thucydides } \\
\text { (460-395 BC) } \\
\text { (The Peloponnesian War) }\end{array}$ & $\begin{array}{l}\text { Pel. war 1.1: } \\
\text { 'Thucydides, an } \\
\text { Athenian, wrote the } \\
\text { history of the war waged } \\
\text { by the Peloponnesians } \\
\text { and the Athenians } \\
\text { against one another'. }\end{array}$ & $\begin{array}{l}\text { Pel. war 1.1: 'in the belief that it } \\
\text { would be great and noteworthy } \\
\text { above all the wars that had gone } \\
\text { before... For this was the } \\
\text { greatest movement that had } \\
\text { ever stirred the Hellenes, } \\
\text { extending also to some of the } \\
\text { barbarians, one might say even } \\
\text { to a very large part of mankind'. }\end{array}$ & $\begin{array}{l}\text { Pel. war 1.1: 'He began the task at the } \\
\text { very outset of the war (from the very } \\
\text { beginning) ...... but from the evidence } \\
\text { which, on pushing my inquiries to the } \\
\text { furthest point' (methodology for } \\
\text { collecting information) }\end{array}$ & None & $1-3-2-3$ \\
\hline $\begin{array}{l}\text { Polybius } \\
\text { (birth: } 208 \mathrm{BC}) \\
\text { (The Histories) }\end{array}$ & $\begin{array}{l}\text { Hist. } 1.1: \text { ' } . . . \text { under what } \\
\text { system of polity the } \\
\text { Romans in less than } \\
\text { fifty-three years have } \\
\text { succeeded in subjecting } \\
\text { nearly the whole } \\
\text { inhabited world to their } \\
\text { sole government - a } \\
\text { thing unique in history' }\end{array}$ & $\begin{array}{l}\text { Extracts from Hist. 1.1-2: 'But all } \\
\text { historians ... have impressed on } \\
\text { us that the soundest education } \\
\text { and training for a life of active } \\
\text { politics is the study of history, } \\
\text { and that the surest and indeed } \\
\text { the only method of learning } \\
\text { how to bear bravely the } \\
\text { vicissitudes of fortune, is to } \\
\text { recall the calamities of others'. } \\
\text { Hist. } 1.4 .- \text { no one has ever tried } \\
\text { to write a general history before. }\end{array}$ & $\begin{array}{l}\text { Hist. 1.3: 'The date from which I propose } \\
\text { to begin is the } 140 \text { th Olympiad, and the } \\
\text { events are the following ...' (the writing } \\
\text { order) } \\
\text { Hist. 1.5: 'I shall adopt as the starting- } \\
\text { point of this book the first occasion on } \\
\text { which the Romans crossed the sea from } \\
\text { Italy. This follows immediately on the } \\
\text { close of Timaeus' History and took place } \\
\text { in the } 129 \text { th Olympiad. Thus we must first } \\
\text { state how and when the Romans } \\
\text { established their position in Italy, and } \\
\text { what prompted them afterwards to cross } \\
\text { to Sicily, the first country outside Italy } \\
\text { where they set foot ...' (the writing order) }\end{array}$ & $\begin{array}{l}\text { Hist. 1.1: 'For the very } \\
\text { element of } \\
\text { unexpectedness in the } \\
\text { events I have chosen as } \\
\text { my theme will be } \\
\text { sufficient to challenge } \\
\text { and incite everyone, } \\
\text { young and old alike, to } \\
\text { peruse my systematic } \\
\text { history'. }\end{array}$ & $2-4-1-2-3-2-3$ \\
\hline $\begin{array}{l}\text { Philostratus (later } 2 \text { nd } \\
\text { century AD - middle of } 3 \text { rd } \\
\text { century AD) } \\
\text { (The Life of Apollonius of } \\
\text { Tyana) }\end{array}$ & $\begin{array}{l}\text { Life Apoll. 1.2: } \\
\text { Philostratus is going to } \\
\text { write about Apollonius } \\
\text { Life Apoll. 1.2: 'but write } \\
\text { a true account of the } \\
\text { man, detailing the exact } \\
\text { times at which he said or } \\
\text { did this or that, as also } \\
\text { the habits and temper of } \\
\text { wisdom by means of } \\
\text { which he succeeded in } \\
\text { being considered a } \\
\text { supernatural and divine } \\
\text { being'. }\end{array}$ & $\begin{array}{l}\text { Life Apoll. 1.2: 'It seems to me } \\
\text { then that I ought not to condone } \\
\text { or acquiesce in the general } \\
\text { ignorance, but write a true } \\
\text { account of the man'. }\end{array}$ & $\begin{array}{l}\text { Life Apoll. 1.2-3: 'And I have gathered my } \\
\text { information partly from the many cities } \\
\text { where he was loved, and partly from the } \\
\text { temples whose long-neglected and } \\
\text { decayed rites he restored, and partly } \\
\text { from the accounts left of him by others } \\
\text { and partly from his own letters ... There } \\
\text { was a man, Damis, by no means stupid, } \\
\text { who formerly dwelt in the ancient city of } \\
\text { Nineveh. He resorted to Apollonius in } \\
\text { order to study wisdom, and having } \\
\text { shared, by his own account, his } \\
\text { wanderings abroad, wrote an account of } \\
\text { them. And he records his opinions and } \\
\text { discourses and all his prophecies ...' (the } \\
\text { source materials used) }\end{array}$ & $\begin{array}{l}\text { Life Apoll. 1.3: 'but let } \\
\text { my work, I pray, } \\
\text { rebound to the honour } \\
\text { of the man who is the } \\
\text { subject of my } \\
\text { compilation, and also } \\
\text { be of use to those who } \\
\text { love learning. For } \\
\text { assuredly, they will } \\
\text { here learn things of } \\
\text { which as yet they were } \\
\text { ignorant'. }\end{array}$ & $1-2-1-3-4$ \\
\hline $\begin{array}{l}\text { Josephus } \\
\text { (A.D. } 37-100 \text { ) } \\
\text { (Jewish Antiquities) }\end{array}$ & $\begin{array}{l}\text { In Ant. } 1.2 .6 \text { he says he } \\
\text { will describe the origin of } \\
\text { the Jews and their } \\
\text { history. }\end{array}$ & $\begin{array}{l}\text { Ant. 1.1: '... others again have } \\
\text { been constrained by the mere } \\
\text { stress of events in which they } \\
\text { themselves took part to set } \\
\text { these out in a comprehensive } \\
\text { narrative; while many have been } \\
\text { induced by prevailing ignorance } \\
\text { of importance affairs of general } \\
\text { utility to publish a history of } \\
\text { them for the public benefit. of } \\
\text { the aforesaid motives the two } \\
\text { last apply to myself ...' }\end{array}$ & $\begin{array}{l}\text { Ant. 1.3: 'I have promised to follow } \\
\text { throughout this work (the Hebrew and } \\
\text { the Greek Scriptures), neither adding nor } \\
\text { omitting anything ...' (faithful to the } \\
\text { Scripture - attitude of writing) } \\
\text { In Ant. } 1.4 \text { Josephus then continues to } \\
\text { describe in what order he will write: he } \\
\text { will speak about Moses, etc. (the writing } \\
\text { order). }\end{array}$ & $\begin{array}{l}\text { Ant. } 1.3: \text { 'the main } \\
\text { lesson to be learnt } \\
\text { from this history ... is } \\
\text { that men who conform } \\
\text { to the will of God, and } \\
\text { do not venture to } \\
\text { transgress laws that } \\
\text { have been excellently } \\
\text { laid down, prosper in } \\
\text { all things beyond belief, } \\
\text { and for their reward } \\
\text { are offered by God } \\
\text { felicity'. }\end{array}$ & $2-1-4-3$ \\
\hline $\begin{array}{l}\text { Josephus } \\
\text { (The Jewish War) }\end{array}$ & $\begin{array}{l}\text { J.W. 1.1.1: He will write } \\
\text { about the Jewish war } \\
\text { with the Romans. }\end{array}$ & $\begin{array}{l}\text { J.W. 1.1.3: 'to provide the } \\
\text { subjects of the Roman Empire } \\
\text { with a narrative of facts, by } \\
\text { translating into Greek the } \\
\text { account which I previously } \\
\text { composed in my vernacular } \\
\text { tongue and sent to the } \\
\text { barbarians in the interior'. }\end{array}$ & $\begin{array}{l}\text { J.W. 1.1.3: He writes as a participant at } \\
\text { the beginning and subsequently an } \\
\text { onlooker (indicate the methodology of } \\
\text { collecting information). } \\
\text { J.W. 1.7-12: describes the writing order } \\
\text { of all } 7 \text { books: from how Antiochus took } \\
\text { over Jerusalem and was later expelled by } \\
\text { the Hasmonaeans; then how the } \\
\text { Hasmonaeans were overthrown by } \\
\text { Herod; then how the war began after } \\
\text { Herod's death, then how the Jews } \\
\text { fortified their towns, then how the } \\
\text { Roman General Vespasian and his son } \\
\text { Titus penetrated into Galilee, then how } \\
\text { the Romans advanced against Jerusalem } \\
\text { and how Jerusalem eventually fell. (the } \\
\text { writing order) }\end{array}$ & None & $1-3-2-3$ \\
\hline
\end{tabular}


TABLE 1 - A1 (Continues...): Analysis of the components used by Greco-Roman Historians in the prefaces of their first books.

Historian (Time) (Writing)

\begin{tabular}{ll} 
& $\begin{array}{l}\text { Description of } \\
\text { Content (1) }\end{array}$ \\
\hline Josephus & $\begin{array}{l}\text { Ag. Ap. 1.1.3: 'I consider } \\
\text { it my duty to devote a } \\
\text { (Against Apion) }\end{array}$ \\
& points...'
\end{tabular}

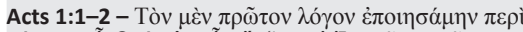

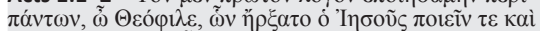

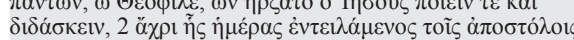

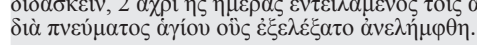

Acts 1:1-2 - In the first book, O Theophilus, I have dealt with all that Jesus began to do and teach, ${ }^{2}$ until the day when he was taken up, after he had given commandm through the Holy Spirit to the apostles whom he had chosen.

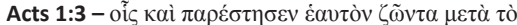

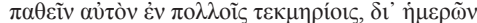

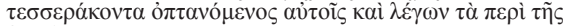

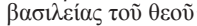

Acts 1:3 - To them he presented himself alive after his passion by many proofs, appearing to them during forty days, and speaking of the kingdom of God

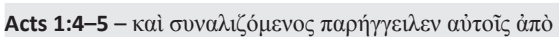

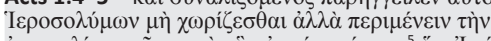

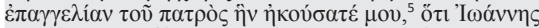

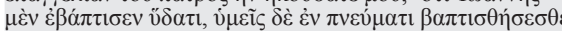

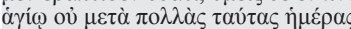

Acts 1:4-5 - And while staying with them he charged them not to depart from Jerusalem, but to wait for the promise of the Father, which, he said, 'you heard from me, ${ }^{5}$ for John baptized with water, but before many days you shall be baptized with the Holy Spirit'.

\section{Components in the Preface of the Historian's First Book}

Description of Reason for Description of Methodology of

Writing (2)

Writing (3)

Ag. Ap. 1.1.2-3: 'I observe that a considerable number of

persons, influenced by the

malicious calumnies of certain

individuals, discredit the

statements in my history
concerning our antiquity, and

adduce as proof of the

comparative modernity of our

race the fact that it has not been

thought worthy of mention by

the best known Greek

historians, I consider it my duty

Ag. Ap. 1.1.3: 'As witnesses to my
statement I propose to call the writers

Description of Order of

who, in the estimation of the Greeks, are

the most trustworthy authorities on

antiquity on a whole. The authors of

scurrilous and mendacious statements

about us will be shown to be confuted by

themselves. I shall further endeavour to

set out the various reasons which explain

why our nation is mentioned by a few

only of the Greek historians; at the same

time I shall bring those authors who have

not neglected our history to the notice of

any who either are, or feign to be,

these parties; in order at once to ignorant of them'. (the writing order)

convict our detractors of

convict our detractors of

malignity and deliberate

falsehood, to correct the

ignorance of others, and to

the truth concerning the

antiquity of our race'.

\section{Corresponding passages in Luke (in Greek and RSV) Observations}

Luke 1-24 - the whole Gospel.

1. Acts 1:1-2 is a brief summary of what Luke has mentioned in his Gospel.
Luke 24:49 - the last verse before the last account in the Gospel: Jesus' ascension

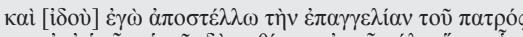

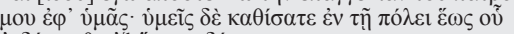

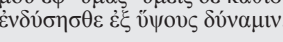

'And behold, I send the promise of my Father upon you;

but stay in the city, until you are clothed with power

from on high'.
1. Acts $1: 3$ is a brief summary of the various accounts of the resurrected Jesus appearing to the apostles and believers and his message about the kingdom of God in Luke 24.

2. The only information Acts has which is not mentioned by the gospel is that Jesus appeared to his apostles for forty days after his resurrection

1. Acts $1: 4$ and Luke $24: 49$ are the only two verses in

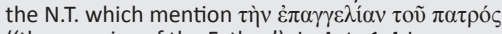
('the promise of the Father'). In Acts 1:4 Jesus says

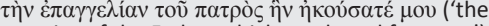
promise of the Father which you heard from me'). This indicates that Jesus must have mentioned $\tau$ ìv

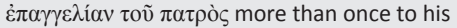
apostles. This must be an important message from Jesus. He gives it repeatedly in the limited time he has with the apostles, and Luke mentions it both has with the apostles, and Luke mentions it both at

2. Most of Acts 1:4 is Luke's paraphrase of Jesus' saying 2. Most of Acts $1: 4$. $24: 49$.
in Luke

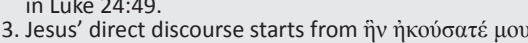

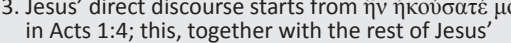
in Acts 1:4; this, together with the rest of Jesus'
discourse in Acts 1:5, elaborates on $\dot{\varepsilon} v \delta \dot{\sigma} \sigma \eta \sigma \theta \varepsilon \dot{\varepsilon} \xi$

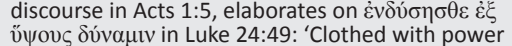

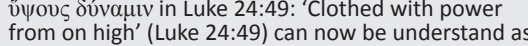
being 'baptized with the Holy Spirit' (Acts 1:5).

4. What Jesus says in Acts 1:5 is very similar to what John the Baptist says in Luke 3:16. Jesus may be paraphrasing what John said in Luke 3:16:

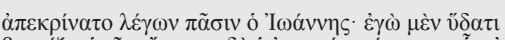

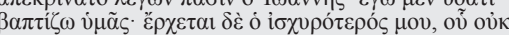

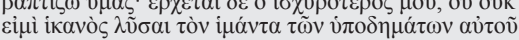

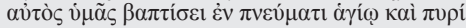

'John answered them all, "I baptize you with water; but he who is mightier than I is coming ... he will baptize you with the Holy Spirit and with fire"'." 